\title{
Archaeologia
}

http://journals.cambridge.org/ACH

Additional services for Archaeologia:

Email alerts: Click here

Subscriptions: $\underline{\text { Click here }}$

Commercial reprints: $\underline{\text { Click here }}$

Terms of use : Click here

\section{XVII.-Remarks on an Admiralty Seal of Richard, Duke of Gloucester}

Charles Spencer Perceval

Archaeologia / Volume 46 / Issue 02 / January 1881, pp 366 - 370

DOI: 10.1017/S0261340900006214, Published online: 25 January 2012

Link to this article: http://journals.cambridge.org/abstract S0261340900006214

How to cite this article:

Charles Spencer Perceval (1881). XVII._Remarks on an Admiralty Seal of Richard, Duke of Gloucester. Archaeologia, 46, pp 366-370 doi:10.1017/S0261340900006214

Request Permissions : $\underline{\text { Click here }}$ 

XVII.-Remarks on an Admiralty Seal of Richard, Duke of Gloucester.
Communicated by Charles Spencer Perceval, Esq., LL.D., Director.

Read January 25, 1872.

The Ven. Edward Trollope, F.S.A., has lately communicated to the Society an impression in gutta-percha from the original matrix ${ }^{a}$ of an Admiralty Seal of Richard III. when Duke of Gloucester, which impression is exhibited this evening.

Another impression from this matrix, then in the possession of a gentleman of St. Columb in Cornwall, was exhibited and presented to the Society in 1781 by Dr. Milles, at that time President, and is still preserved.

It will be found engraved in the seventh volume of the Archeologia, plate v. page 69 , with some illustrative remarks by the learned doctor, and it is with the object of correcting an error into which he has fallen that $I$ am induced to offer the following observations.

The seal, which needs no minute description, exhibits, like others of the same class, a ship with the Duke's arms on the mainsail. The legend runs thus :-

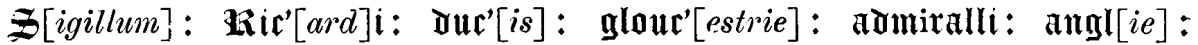
$\mathfrak{i}^{\prime}[n]: \mathfrak{c o m}^{\prime}[$ itatibus $]: \mathbb{B a r s}[$ etie $] \mathfrak{t}[$ et $]: \mathscr{S} \mathfrak{o m}[$ er $] \mathfrak{s}[$ etie $]$.

"The seal of Richard, Duke of Gloucester, Admiral of England, in the connties of Dorset and Somerset."

Dr. Milles unfortunately took the character $\overline{\mathfrak{i}}$, standing as usual for $i n$, as a contraction for et, and consequently he read " et comitis Dorset' et Somerset" ".

Hence he concluded that the seal preserved evidence of a fact as to which the records are silent, namely, that Richard, Duke of Gloucester was also Earl of Dorset and Somerset.

"It seems extraordinary," says Dr. Milles, "that there should be so little historical authority extant for the titles given to the Duke in this inscription."

a The matrix has since been acquired by the British Museum. 
"Sir Henry Spelman indeed mentions"him in the list of Admirals inserted in the Glossary, with the date of October 12th, but no year annexed; and again inserts his name as Lord High Admiral in the 11th of Edward IV." Sandford, he continues, in his Genealogical History, "states that shortly after the coronation of Edward, Richard was created Duke of Gloucester and thereupon constituted Admiral of England."

Dr. Milles then shows that this last statement is incorrect, for Richard Nevill, Earl of Warwick, was Admiral of England at the date of the duke's creation, Nov. 1, 1461, and so continued until July 13, 1462, when William, Earl of Kent, was appointed. (Rymer, xi. 490.) He adds that the latter did not long enjoy the station, for upon August 12 in the same year the King granted by patent ( 2 Ed. IV. pars. 1a, m. 5, and Rot. Parl. vi. 227) to the Duke the Castie of Gloucester, the office of Constable of Corfe Castle, the manor of Kingston Lacy in the county of Dorset, and other lands, addressing him in the letters patent as "Maris Admirallum."

Dr. Milles concludes with a laboured attempt to explain his imaginary earldom of Dorset and Somerset, and would date the seal between 1471 when it seems the Duke had a grant of the office of High Admiral, and 1475, when the Marquisate of Dorset was conferred on Thomas Grey.

Now it is certain that Richard was constituted Admiral of England, Ireland, and Aquitaine, that is, Lord High Admiral, by letters patent bearing date October 11, 1462, and at first sight the seal might be referred to this date, and might be a special seal for his jurisdiction in Dorset and Somerset. From the absence however of the words "Hibernie et Acquitanie" in the legend, I am disposed to think that the Duke was not Lord High Admiral when the seal was made, but had at that time a local or vice-admiralty jurisdiction in the two named counties. I find that the lords of Corfe Castle down to the middle of the last century enjoyed the admiralty jurisdiction over the isle of Purbeck, and it is not impossible that a more extended franchise may have accompanied or preceded the grant of Corfe Castle and the other subjects of the letters patent of August 1462.

The late Mr. J. T. Pettigrew, F.S.A., having procured the loan of the matrix, communicated about 1862 a paper on this and other Admirals' seals to the British Archrological Association, and it was subsequently printed in the first volume of their Collectanea Archaologica, p. 171.

Through inattention to the legend he fell into the same trap with Dr. Milles as to the imaginary earldom of Dorset and Somerset, and found no better way 
out of the difficulty than by adopting with some slight variation. his predecessor's attempt at an explanation.

Mr. Pettigrew however did good service by re-engraving on one plate the seal in question with four more of the same class, and he appended a list of the examples of such seals which were known to him.

This list is derived without addition from that drawn up by that excellent antiquary the late Mr. John Gough Nichols as long ago as 1825, ${ }^{\mathrm{a}}$ and comprises the following seven seals :

1. Thomas Beaufort, Duke of Exeter, 1416, son of John of Gaunt by Catherine Swinburne. Figured in Archeologia, XIV. 278, pl. xlvii. fig. 5 ; but wrongly attributed there to Thomas Holand, Duke of Exeter. The matrix is in the British Museum. Collect. Archaol. pl. xv. fig. 2.

2. John Holand, Earl of Huntingdon, as Lieutenant-General to John, Duke of Bedford, c. 1415. Figured in Gents. Mag. lxvii. 549. Collect. Archaol. pl. xv. fig. 3.

3. The same, as Admiral of England and Ireland, 1435. Figured in Ducarel's History of St. Katherine's Hospital, and repeated in Gents. Mag. xcv. part i. p. 209. Collect. Archeol. pl. xv. fig. 4.

4. The same, as Earl of Huntingdon, Lord of Ivory, and Admiral of England, Ireland, and Acquitaine. Figured in Archroologia, XVIII. 434. Collect. Archaol. pl. xv. fig. 5. The matrix, of copper gilt, is in the British Museum.

5. Henry Holand, Duke of Exeter, son of the above. Figured in Dr. Rawlinson's Topographer.

6. Richard, Duke of Gloucester ; the seal under consideration.

7. A vice-admiral's seal for Yorkshire. Figured in Gents. Mag. Dec. 1825, pl. ii. fig. 2 , p. 497 , but not identified satisfactorily, owing to a break in the legend, which appears to be-

$$
\mathcal{S} \cdot \text { Hob' }^{\prime} \cdot \mathbf{r o} \text {. orap } \cdot \text { admiralli angl' in } \cdot \text { com } \cdot \text { (Epbor' }
$$

This legend illustrates that of the Duke of Gloucester's seal, lending some confirmation to the surmise that it is a vice-admiralty seal. The seal is comparatively late, as the Scottish lion is quartered on the mainsail of the ship, but it is evidently copied or altered from a much older seal, if we may judge by the fifteentl century lettering, and the course of quaterfoils which surround the legend.

To these may be added the following seals of English admirals or vice-admirals, some unedited, but of which casts exist in the Society's collection. I purposely omit the seals of admiralty jurisdictions in the hands of the corporations of certain 
towns, as Boston, Malden, Yarmouth, all of which have the ship for their device, as to discuss these would occupy too much time and space.

8. Edward, Earl of Rutland and Cork, son and heir apparent of Edmund of Langley, Duke of York, Admiral of the North and West, 1391. 'S' (êtwardi : comitis: : de : (Roteland) $\mathfrak{t}: \mathfrak{d e}:$ Gork : admirali : anglie.

9. Richard Cletherowe, Admiral of the West of England, 1406. Inscribed,

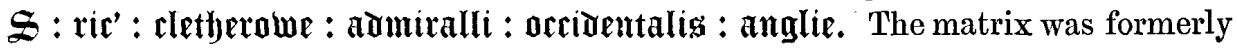
in Horace Walpole's collection at Strawberry Hill, afterwards belonged to Dr. Bliss, and is now in the British Museum.

10. Sir William Hilton, Admiral (of the Humber towards Scotland), c. 1420. כatillum . Izilton . miles . admiralis . pro . loco . bubre . usq' : scotia.'

11. Thomas Howard, Duke of Norfolk, High Admiral, 1514. From deed in Augmentation Office, Dd. 1. A fragment, legend wanting.

12. John Russell, first Earl of Bedford of that name, K.G. Admiral of England and Irelaud, 1540. A fragment s.Ma[GNUM]. . . . . ETAnie.

13. Charles, Lord Howard of Effingham, 1585, High Admiral. SIGIL D $^{*}$ CAROLI - HOWARD BARON ' DE - EFFINGHAM PRACLARI - ORD'IS - PRESCELIDIS • MILITIS $\cdot$ MAGNI ADMIRALLI $\cdot$ ANGLIæ $\cdot$ ET $\cdot$ CET $\cdot A^{0} \cdot 1585$. Figured in Hones' Table Book, i. 574.

14. James, Duke of York, High Admiral, 1660. SIGIL - ILLfST - IACOBI · DVCIS ' EBOR \& ALBAN ' COM ' VLTON ' SVMMI ANGLI \& \& HIB - ARCHITHAL GVARD $\cdot$ QVINQ $\cdot$ PORT $\cdot$ PRECLA ORD $\cdot$ GAR $\cdot$ MIL, \&c. Engraved by T. Simon ; see Vertue, Medals, \&c. of Thomas Simon, pl. xxxviii. Simon had executed a very similar seal for the Earl of Northumberland, as Lord High Admiral.

15. Arthur Plantagenet, Lord Lisle, natural son of Edward IV. Vice-Admiral or Lieutenant to Henry Fitzroy, Duke of Richmond and Somerset, natural son of Henry VIII. from two examples, dated 1526, at Exeter and Canterbury. \&. one (sic) arthur: 羽antaginet: bicomitig lislle(?) uice : armiralli: anglie : bibernie : et: acpuipta (sic).

16. Michael Stanhope, Esq., Vice-Admiral of the county of Suffolk, temp. Hen. VIII. Inscribed SIgILLV MICHAELIS ' STANHOPE ' ARMIGERI - VICEAdMIRALLI $\cdot$ COMITATVS $\cdot$ SVFFOLCIE.

17. John Basset, of Tehidy, Vice-Admiral of the north parts of Cornwall, early in the seventeenth century. Described in Archaological Journal, xx. 78. The inscription reads SIGI : IOH : BASSETT : ARM : VICEADM : PARTIV : BOREALIV : COM : CORNVBIE.

18. Colonel John Owen, Vice-Admiral of North Wales, seventeenth century. voL. XlVI. 
Inscribed IOHN - OWEN . COLL . VICE - ADMIRALL . NORTH WALliENsis. Silver matrix at Porkington.

Although I do not propose to enlarge upon the foreign seals of admirals, it may be well to mention that of John, bastard of Bourbon, Admiral of France in 1466, the matrix of which was exhibited to the Society by Lord Braybrooke on Feb. 26, 1835. See Archaologia, XXVI. 479, where it is figured. It closely resembles in design the seals of English admirals, as does also the seal of Maximilian of Burgundy, 1543, of which a full description will be found in The Archaological Journal, vol. x. p. 146.

The French seals of admirals must be rare, as only two are noticed in Douet d'Areq, Collection de Sceaux (tom. i. p. 298), of the dates 1514 and 1738. 